\title{
Delineation of a coastal gray whale feeding area using opportunistic and systematic survey effort
}

\author{
Judy E. Muir ${ }^{1,8, *}$, Ruth Joy ${ }^{2}$, Yury Bychkov ${ }^{1}$, Koen Bröker ${ }^{3}$, Glenn Gailey ${ }^{4,9}$, \\ Valeriy Vladmirov ${ }^{5}$, Sergei Starodymov ${ }^{6}$, Yuri Yakovlev ${ }^{7}$ \\ ${ }^{1}$ LGL Limited environmental research associates, Sidney, British Columbia V8L 3Y8, Canada \\ ${ }^{2}$ Department of Statistics \& Actuarial Science, Simon Fraser University, Burnaby, British Columbia V5A 1S6, Canada \\ ${ }^{3}$ Shell Global Solutions, Lange Kleiweg 40, 2288GK Rijswijk, The Netherlands \\ ${ }^{4}$ Marine Mammal Research Program, Texas A\&M University at Galveston, Galveston, TX 77553, USA \\ ${ }^{5}$ Russian Marine Mammal Council, Nakhimovskiy ave. 36, 117218 Moscow, Russia \\ ${ }^{6}$ ExxonMobil Russia Inc., 31 Novinsky b-r 31, 123242 Moscow, Russia \\ ${ }^{7}$ A.V. Zhirmunsky Institute of Marine Biology, Far Eastern Branch of the Russian Academy of Sciences (IMB FEB RAS), \\ 690041 Vladivostok, Russia \\ ${ }^{8}$ Present address: Muir Ecological Services Ltd., Victoria, British Columbia V8R 4J1, Canada \\ ${ }^{9}$ Present address: Cascadia Research Collective, 218 1/2 W. 4th Ave, Olympia, WA 98501, USA
}

\begin{abstract}
A seismic survey took place during June and July 2010 adjacent to the gray whale (Eschrichtius robustus) coastal feeding area on the northeast Sakhalin Shelf, Russia. Seismic surveys produce underwater sound that can cause hearing injury and behavioural disturbance in marine mammals. In addition to common mitigation measures to prevent acoustic injury, mitigation measures to avoid behavioural disturbance to gray whales within the feeding area were applied. This behavioural mitigation required delineation of the feeding area; however, no clear boundary was obvious because gray whale distribution within the feeding ground varies within and across years. We estimated the feeding area's offshore boundary using a $1.0 \mathrm{~km}^{2}$ gray whale relative density surface derived from systematic and opportunistic survey data collected during June and July 2005 to 2007 . We calculated a separate surface for each of the systematic and opportunistic data sets, then calibrated and merged the 2 surfaces. We evaluated 3 geostatistical kriging methods (ordinary, simple, and co-kriging) that were applied to the merged surface to estimate a smoothed surface across areas with and without survey effort. Simple kriging was most suitable due to its ability to transition over sharp gradients in whale abundance and provide reasonable predictions in data-void areas. A 95\% abundance contour of the kriged surface was used as an estimate of the feeding area boundary. Our approach provided an objective and quantitative basis to delineate the feeding area boundary to support measures taken to mitigate the potential impacts of the seismic survey on the whales.
\end{abstract}

KEY WORDS: Gray whale - Eschrichtius robustus · Feeding area $\cdot$ Critical habitat $\cdot$ Seismic survey mitigation $\cdot$ Abundance surface $\cdot$ Systematic surveys $\cdot$ Opportunistic surveys $\cdot$ Kriging

\section{INTRODUCTION}

The summer range of gray whales Eschrichtius robustus includes 2 feeding areas on the northeast Sakhalin Shelf, Russia (Meier et al. 2007). An approximately $120 \mathrm{~km}$ long and $10 \mathrm{~km}$ wide nearshore 'Pil-

${ }^{*}$ Corresponding author: jemuir@telus.net tun' feeding area is located adjacent to the coast of Sakhalin Island. A deeper 'Offshore' feeding area is situated $\sim 45 \mathrm{~km}$ southeast of the Piltun feeding area in water $\sim 40$ to $50 \mathrm{~m}$ deep. Higher densities of gray whales are typically observed in the Piltun area than the Offshore area (Vladimirov et al. 2013). The Piltun 
area is also an important habitat for cow-calf pairs and for newly weaned calves (Sychenko 2011).

The Sakhalin Shelf contains extensive oil and gas reserves presently being developed. Sakhalin Energy Investment Company Ltd. (hereafter Sakhalin Energy) conducted a repeat 3-dimensional (4-D) seismic survey in June and July 2010 to map production-related changes in subsea oil and gas reserves. The $167 \mathrm{~km}^{2}$ seismic survey area was located approximately 10 to $25 \mathrm{~km}$ offshore, adjacent to the southern portion of the Piltun feeding area. Seismic surveys produce underwater sound that can cause hearing injury and behavioural changes in marine mammals (Richardson et al. 1995, Nowacek et al. 2007). Documented effects of acoustic disturbance on baleen whales range from minor changes in surfacing behaviour and respiration rates to displacement from areas closest to the sound source (Reeves et al. 1984, Richardson et al. 1986, 1999, Ljungblad et al. 1988, McCauley et al. 2000, Gailey et al. 2007a, Yazvenko et al. 2007). In particular, Malme et al. (1986) found $\sim 10 \%$ of gray whales stopped feeding and moved away from pulsed airgun sounds exceeding $163 \mathrm{~dB}$ re $\mu \mathrm{Pa}$ rms.

Preliminary acoustic modelling for the 4 -D seismic survey indicated that parts of the Piltun feeding area could be exposed to sound levels above $163 \mathrm{~dB}$ re $\mu \mathrm{Pa}$ rms (IUCN 2007). Consequently, a monitoring and mitigation plan (MMP) was developed that used an equivalent per-pulse sound exposure value of $156 \mathrm{~dB}$ re $\mu \mathrm{Pa}^{2}$-s (156 dB SEL) as a threshold level for disturbance of gray whale behaviour (Bröker et al. 2015). The MMP required estimation of the Piltun feeding area boundary to delineate areas ('A-zones') within the feeding ground where sound levels exceeded $156 \mathrm{~dB}$ SEL. A-zones were defined for each survey line sailed by the seismic vessel as the overlap between the $156 \mathrm{~dB}$ SEL contour generated by the seismic source when acquiring that line $\mathrm{e}^{\mathbf{1}}$ and the Piltun feeding area boundary. Each A-zone was required to be clear of gray whales when that Azone's line was sailed.

Higher densities of gray whales in the Piltun feeding area have been observed in water depths of $<25 \mathrm{~m}$ and between the latitudes of approximately

\footnotetext{
${ }^{1}$ Seismic acquisition involves the generation and recording of seismic data using a source, such as an airgun array, and different receiver configurations, e.g. a string of hydrophones towed behind a seismic vessel. The source generates acoustic or elastic vibrations that travel into the sea bottom, pass through strata with different seismic responses and filtering effects, and return to the surface to be recorded
}

$52^{\circ} 20^{\prime} \mathrm{N}$ to $53^{\circ} 30^{\prime} \mathrm{N}$ (Fadeev et al. 2012), but no clear boundary for the feeding area was obvious because distribution varies within and among years (Meier et al. 2007, Vladimirov et al. 2013). Amphipods and isopods are preferred prey in the Piltun feeding area; however, bivalve molluscs, worms, and sand lance Ammodytes hexapterus are also eaten opportunistically (Fadeev 2013). These prey have a patchy spatial distribution, and locations of high biomass vary across years, although higher biomasses are generally found in water 5 to $20 \mathrm{~m}$ deep that is typically located within $5 \mathrm{~km}$ of shore (Fadeev 2013).

The MMP defined the feeding area boundary as the line incorporating $95 \%$ of estimated gray whale abundance in the Piltun feeding area during the planned June-July time frame of the seismic survey (IUCN 2008). A $95 \%$ abundance contour is commonly used to delineate individual and species' geographic range boundaries (Worton 1987, Laver \& Kelly 2008, Kie et al. 2010). This paper presents the methods we used to estimate the boundary based on data from both systematic and opportunistic survey effort. While considerable systematic shore-based effort was available, spatial coverage of the feeding ground was constrained in some areas by lowelevation observation stations. Systematic vessel surveys provided some additional coverage in this vicinity, but effort was limited. The vessels used for systematic surveys spent 3 to 4 mo each season conducting other research (e.g. benthos sampling or photo-identification) on the northeast Sakhalin shelf. Marine mammal observers (MMOs) were on watch during daylight hours when environmental conditions permitted, thus providing considerable opportunistic effort that filled in some of the temporal and spatial gaps in systematic survey effort within the Piltun feeding ground and surrounding areas. Our approach calibrated and combined the 2 data sets to produce a smoothed surface for which a $95 \%$ abundance contour was estimated as a proxy of the Piltun feeding area boundary.

\section{MATERIALS AND METHODS}

\section{Survey effort}

Data from systematic and opportunistic survey effort during June and July 2005 to 2007 were used to characterize recent gray whale distribution patterns in the study area. Shore-based and vessel-based surveys systematically sampled gray whale distribution and abundance within the Piltun feeding area and its 


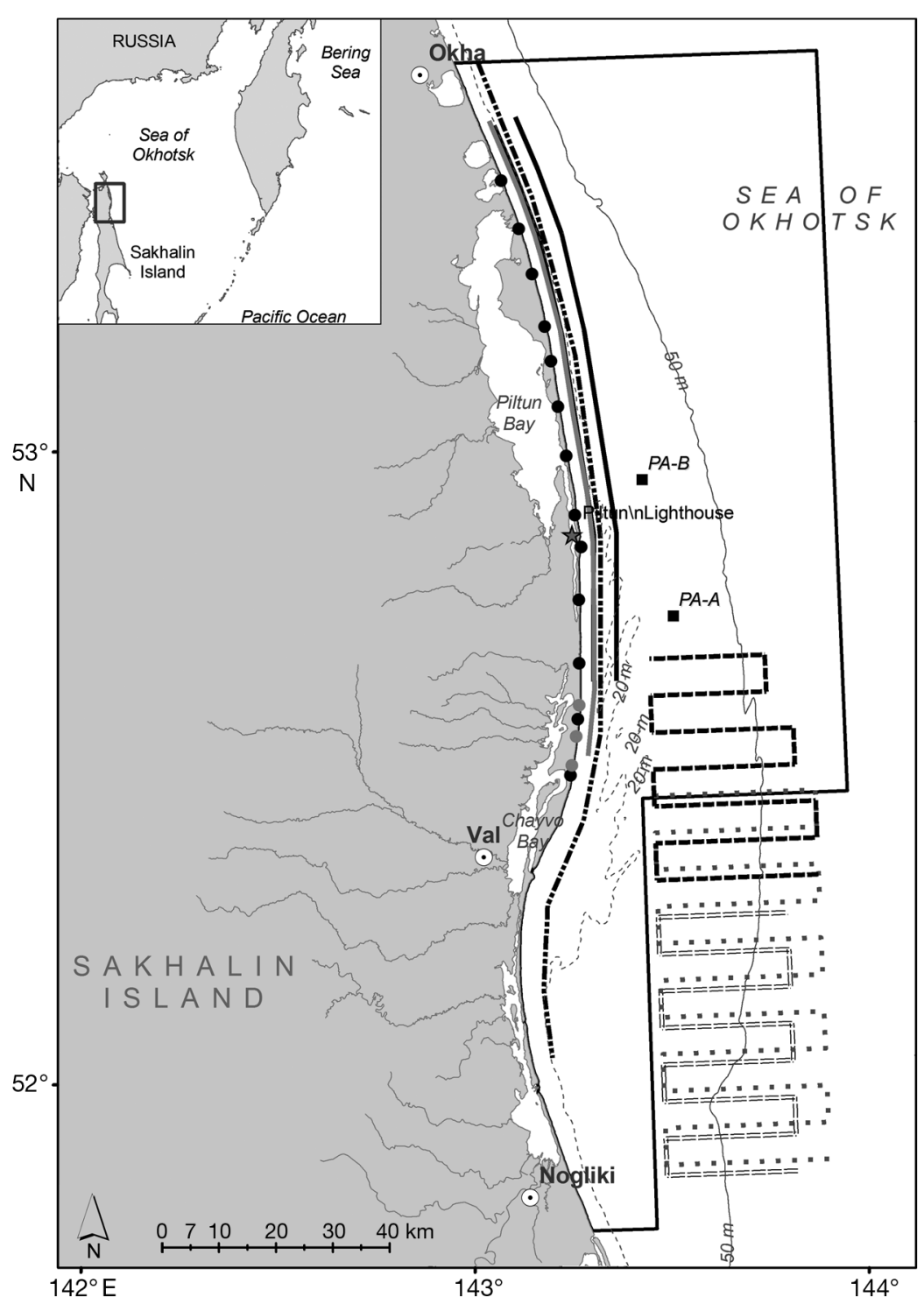

Fig. 1. Northeast Sakhalin shelf with Sakhalin Energy platforms (PA-A and PAB) indicated as black squares. The shore-based observation stations (Table 1) are shown as black (2005-2007) and gray (2006 only) circles. Systematic vessel survey transects are designated by different line styles and shades. Piltun survey transects are represented as solid gray (2005), solid dark (2006) and dot/dashed (2007) lines in coastal waters. Arkutun-Dagi transects (2006-2007) are black dashed lines. Offshore feeding area transects that provided additional sightings for detection function estimation are shown as gray dots (2005) and gray double lines (2006-2007). The spatial extent used for analysis is indicated by the black polygon

surroundings (Fig. 1). Shore-based scan surveys were conducted daily throughout each field season, weather permitting, from several permanent observation stations along the coast (our Tables 1 \& 2; Gailey et al. 2007b, 2008, Vladimirov et al. 2007, 2008). MMOs used Fujinon FMTRC-SX $7 \times 50$ reticle binoculars to scan the nearshore waters surrounding a station at a constant rate. Bearing, reticle estimate, and number of individuals were recorded for each sighting. MMOs also recorded environmental conditions for each scan at an observation station (Beaufort wind force scale [hereafter Beaufort Scale], visibility in $\mathrm{km}$, wind speed and direction, presence and location of glare, and swell height).

Systematic vessel surveys were conducted up to a few times monthly using large vessels (mean length $74 \mathrm{~m}$ ) in 3 areas of the northeast Sakhalin shelf (Vladimirov et al. 2007, 2008; Fig. 1, Table 3). Transects in the Piltun feeding area ('Piltun survey') were located parallel to shore. A single transect was sailed at distances of $2.5 \mathrm{~km}$ (2005) and $4 \mathrm{~km}$ (2007) from shore. The 2006 survey sampled 2 transects at 2.5 and 6.5 $\mathrm{km}$ from shore. Vessel surveys of the Offshore feeding area were conducted in 2005 along 11 east-west transects 28 $\mathrm{km}$ in length spaced $6.5 \mathrm{~km}$ apart. The 'Offshore survey' was redesigned in 2006 when the survey grid was shifted south by $2 \mathrm{~km}$ and the 8 southerly transects were retained and shortened to $23 \mathrm{~km}$. A new 'Arkutun-Dagi survey' in 2006 sampled the deeper-water Arkutun-Dagi licence block adjacent to the southern part of the Piltun feeding area. The Arkutun-Dagi survey consisted of the remaining 3 northerly transects from the 2005 Offshore survey, with the addition of 4 transects to the north that were also spaced at $6.5 \mathrm{~km}$ intervals. Vessels sailed at 10 knots (Piltun) or 11 knots (Offshore, Arkutun-Dagi). Surveys were conducted only in good visibility $(>5 \mathrm{~km})$ and Beaufort Scale <4. Two MMOs were on watch during the systematic surveys in 2005. One or two MMOs were on watch in 2006, and a single MMO was on watch in 2007. In 2005, MMOs estimated the distance to a marine mammal sighting by eye when the animal was abeam of the vessel. Protocols were amended in 2006 to record distance and bearing at first detection. Distance was estimated using Fujinon FMTRC-SX $7 \times 50$ reticle binoculars, and the ship's gyrocompass was used to estimate the azimuth to the sighting. 
Table 1. Shore-based observation stations. Stations are numbered in order from north to south. The location and mean station height in 2005 to 2007 is provided. Station height is at mean low water. Stations marked with * were sampled in 2006. Stns 11, 12, 13 and 19 were moved prior to the 2006 field season. Footnotes describe the change in station location from 2005 to 2006 and provide the 2005 coordinates and height

\begin{tabular}{|c|c|c|c|}
\hline Station & $\begin{array}{l}\text { Latitude } \\
\left({ }^{\circ} \mathrm{N}\right)\end{array}$ & $\begin{array}{l}\text { Longitude } \\
\qquad\left({ }^{\circ} \mathrm{E}\right)\end{array}$ & $\begin{array}{l}\text { Mean height } \\
(\mathrm{m})\end{array}$ \\
\hline 1 & 53.413 & 143.153 & 13.1 \\
\hline 2 & 53.335 & 143.196 & 18.1 \\
\hline 3 & 53.306 & 143.210 & 18.5 \\
\hline 4 & 53.264 & 143.227 & 27.0 \\
\hline 5 & 53.209 & 143.248 & 16.4 \\
\hline 6 & 53.180 & 143.256 & 14.6 \\
\hline 7 & 53.125 & 143.270 & 8.5 \\
\hline 8 & 53.053 & 143.285 & 8.1 \\
\hline 9 & 52.974 & 143.302 & 9.6 \\
\hline 10 & 52.890 & 143.318 & 5.4 \\
\hline $11^{\mathrm{a}}$ & 52.881 & 143.320 & 7.0 \\
\hline $12^{\mathrm{b}}$ & 52.830 & 143.333 & 6.0 \\
\hline $13^{\mathrm{c}}$ & 52.747 & 143.323 & 7.0 \\
\hline $14^{*}$ & 52.646 & 143.318 & 7.7 \\
\hline 15 & 52.580 & 143.315 & 5.1 \\
\hline $16^{*}$ & 52.558 & 143.311 & 9.8 \\
\hline $17^{*}$ & 52.531 & 143.305 & 7.2 \\
\hline 18 & 52.486 & 143.291 & 6.8 \\
\hline $19^{\mathrm{d}}$ & 52.470 & 143.287 & 7.0 \\
\hline \multicolumn{4}{|c|}{ 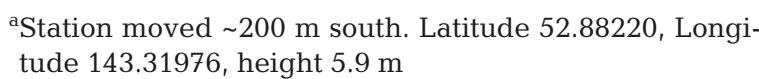 } \\
\hline \multicolumn{4}{|c|}{$\begin{array}{l}{ }^{\mathrm{b}} \text { Station moved } \sim 325 \mathrm{~m} \text { southwest. Latitude } 52.83290 \text {, } \\
\text { Longitude 143.33437, height } 5.3 \mathrm{~m}\end{array}$} \\
\hline \multicolumn{4}{|c|}{$\begin{array}{l}{ }^{\mathrm{c}} \text { Station moved } \sim 20 \mathrm{~m} \text { northwest. Latitude } 52.74653 \text {, Lon- } \\
\text { gitude } 143.32310 \text {, height } 6.0 \mathrm{~m}\end{array}$} \\
\hline \multicolumn{4}{|c|}{$\begin{array}{l}\text { dStation moved } \sim 225 \mathrm{~m} \text { southwest. Latitude } 52.47182 \text {, } \\
\text { Longitude } 143.28783 \text {, height } 7.0 \mathrm{~m}\end{array}$} \\
\hline
\end{tabular}

Table 2. Shore-based scan effort by year. The total number of stations at which a scan was conducted during June or July is shown for each year. The number of sightings and gray whales are also shown. Scans were conducted from an additional 3 stations adjacent to the southern Piltun feeding area in 2006

\begin{tabular}{|ccccc|}
\hline Year & Field start date & Scans & Sightings & Gray whales \\
\hline 2005 & 25 Jun-31 Jul & 247 & 1009 & 1253 \\
2006 & 20 Jun-31 Jul & 308 & 880 & 1089 \\
2007 & 20 Jun-31 Jul & 283 & 423 & 498 \\
Total & & 838 & 2312 & 2840 \\
\hline
\end{tabular}

Vessels involved in work other than systematic whale surveys were required to remain at least $4 \mathrm{~km}$ from shore (approximately the $20 \mathrm{~m}$ isobath) when operating in the Piltun feeding area, unless conducting research activities that required the vessel to
Table 3. Systematic vessel survey effort on the northeast Sakhalin shelf during the period June to October from 2005 to 2007 . The number of on-effort gray whale sightings and individual gray whales recorded during each survey is shown. Arkutun-Dagi surveys began in 2006

\begin{tabular}{|c|c|c|c|}
\hline $\begin{array}{l}\text { Year } \\
\text { Survey location }\end{array}$ & Survey dates & $\begin{array}{l}\text { No. of } \\
\text { sightings }\end{array}$ & $\begin{array}{c}\text { No. of } \\
\text { whales }\end{array}$ \\
\hline \multicolumn{4}{|l|}{2005} \\
\hline \multirow[t]{8}{*}{ Piltun } & $16 \mathrm{Jul}$ & 30 & 34 \\
\hline & $11 \mathrm{Aug}^{\mathrm{a}}$ & 32 & 46 \\
\hline & 18 Aug & 42 & 57 \\
\hline & 28 Aug & 42 & 50 \\
\hline & $5 \mathrm{Sep}^{\mathrm{a}}$ & 19 & 23 \\
\hline & $18 \mathrm{Sep}$ & 52 & 67 \\
\hline & 29 Sep & 42 & 55 \\
\hline & $1 \mathrm{Oct}^{\mathrm{a}}$ & 19 & 32 \\
\hline \multirow[t]{5}{*}{ Offshore } & 10 Aug & 0 & 0 \\
\hline & 19 Aug & 1 & 1 \\
\hline & $6 \mathrm{Sep}$ & 3 & 5 \\
\hline & $17 \mathrm{Sep}$ & 13 & 18 \\
\hline & $2 \mathrm{Oct}$ & 11 & 21 \\
\hline \multicolumn{4}{|l|}{2006} \\
\hline \multirow[t]{5}{*}{ Piltun } & 27 Jun & 17 & 25 \\
\hline & $23 \mathrm{Jul}^{\mathrm{a}}$ & 22 & 33 \\
\hline & $23 \mathrm{Aug}$ & 52 & 76 \\
\hline & 11 Sep & 23 & 38 \\
\hline & 30 Sep & 38 & 66 \\
\hline \multirow[t]{4}{*}{ Offshore } & 30 Jun & 0 & 0 \\
\hline & $25 \mathrm{Aug}$ & 5 & 7 \\
\hline & $15 \mathrm{Sep}$ & 13 & 43 \\
\hline & 7 Oct & 15 & 25 \\
\hline \multirow[t]{4}{*}{ Arkutun-Dagi } & 28 Jun & 0 & 0 \\
\hline & $12 \mathrm{Jul}$ & 0 & 0 \\
\hline & 11 Aug & 1 & 1 \\
\hline & $4 \mathrm{Oct}^{\mathrm{a}}$ & 0 & 0 \\
\hline \multicolumn{4}{|l|}{2007} \\
\hline \multirow[t]{4}{*}{ Piltun } & 5 Aug & 28 & 45 \\
\hline & $7 \mathrm{Sep}$ & 26 & 45 \\
\hline & 3 Oct & 18 & 22 \\
\hline & 4 Oct & 16 & 30 \\
\hline \multirow[t]{6}{*}{ Offshore } & $30 \mathrm{Jul}^{\mathrm{a}}$ & 4 & 6 \\
\hline & $31 \mathrm{Jul}$ & 13 & 36 \\
\hline & $15 \mathrm{Aug}$ & 12 & 35 \\
\hline & $1 \mathrm{Sep}$ & 16 & 25 \\
\hline & 15 Sep & 19 & 33 \\
\hline & 1 Oct & 18 & 35 \\
\hline \multirow[t]{6}{*}{ Arkutun-Dagi } & $30 \mathrm{Jul}$ & 0 & 0 \\
\hline & $16 \mathrm{Aug}$ & 0 & 0 \\
\hline & 25 Aug & 2 & 2 \\
\hline & 6 Sep & 0 & 0 \\
\hline & 14 Sep & 2 & 2 \\
\hline & 30 Sep & 0 & 0 \\
\hline \multicolumn{4}{|c|}{ ancomplete surveys } \\
\hline
\end{tabular}

enter shallower water. In such cases, the vessel draft restricted it to waters $>10 \mathrm{~m}$ deep. Two MMOs were on watch in 2005; a single MMO was on duty during 2006 and 2007. The opportunistic MMO protocols recorded the same attributes for sightings and envi- 
ronmental conditions as those recorded for systematic surveys. Vessel GPS tracks were also recorded. Opportunistic surveys therefore provided considerable and complementary effort in deeper waters of the Piltun feeding area and on the Sakhalin shelf, although vessel speeds and environmental conditions varied considerably.

\section{Approach used to estimate the feeding area boundary}

Our approach to use systematic and opportunistic effort to estimate a $95 \%$ gray whale abundance contour of the Piltun feeding area consisted of 4 main steps (Fig. 2) that (1) separately estimated a relative density surface (whales per $\mathrm{km}^{2}$, hereafter WPKM ${ }^{2}$ ) and whales per unit effort (WPUE) surface for the systematic and opportunistic data sets respectively, (2) calibrated and merged the 2 surfaces, (3) applied geostatistical kriging methods to the merged surface to estimate a smoothed surface across areas with and without survey effort, and (4) delineated a contour enclosing $95 \%$ of the estimated abundance in the resulting surface to represent the Piltun feeding area boundary. The spatial extent used for analysis was a bounding box of spatial coverage by both data sets, with exclusion of the Offshore feeding area so that its high gray whale abundance would not influence the boundary estimation. Details for each analysis stage are presented below.

\section{Systematic WPKM ${ }^{2}$ surface estimation}

The study area was overlaid with a grid of $1.0 \mathrm{~km}^{2}$ cells and a gray whale density estimated for each grid cell sampled by each systematic survey from a vessel transect or onshore station during June-July 2005-2007. Gray whale sightings were corrected for availability and detection biases that typically underestimate abundance (Marsh \& Sinclair 1989). These correction factors were estimated separately for each platform. The correction for availability, i.e. the probability that a gray whale was on the ocean surface and available to be detected $(\hat{a})$, was estimated for each year and survey platform based on McLaren (1961) using mean gray whale dive cycle times measured in the field (Gailey et al. 2007b, 2008). Distance sampling (Buckland et al. 2001, 2004) was used to analyse the

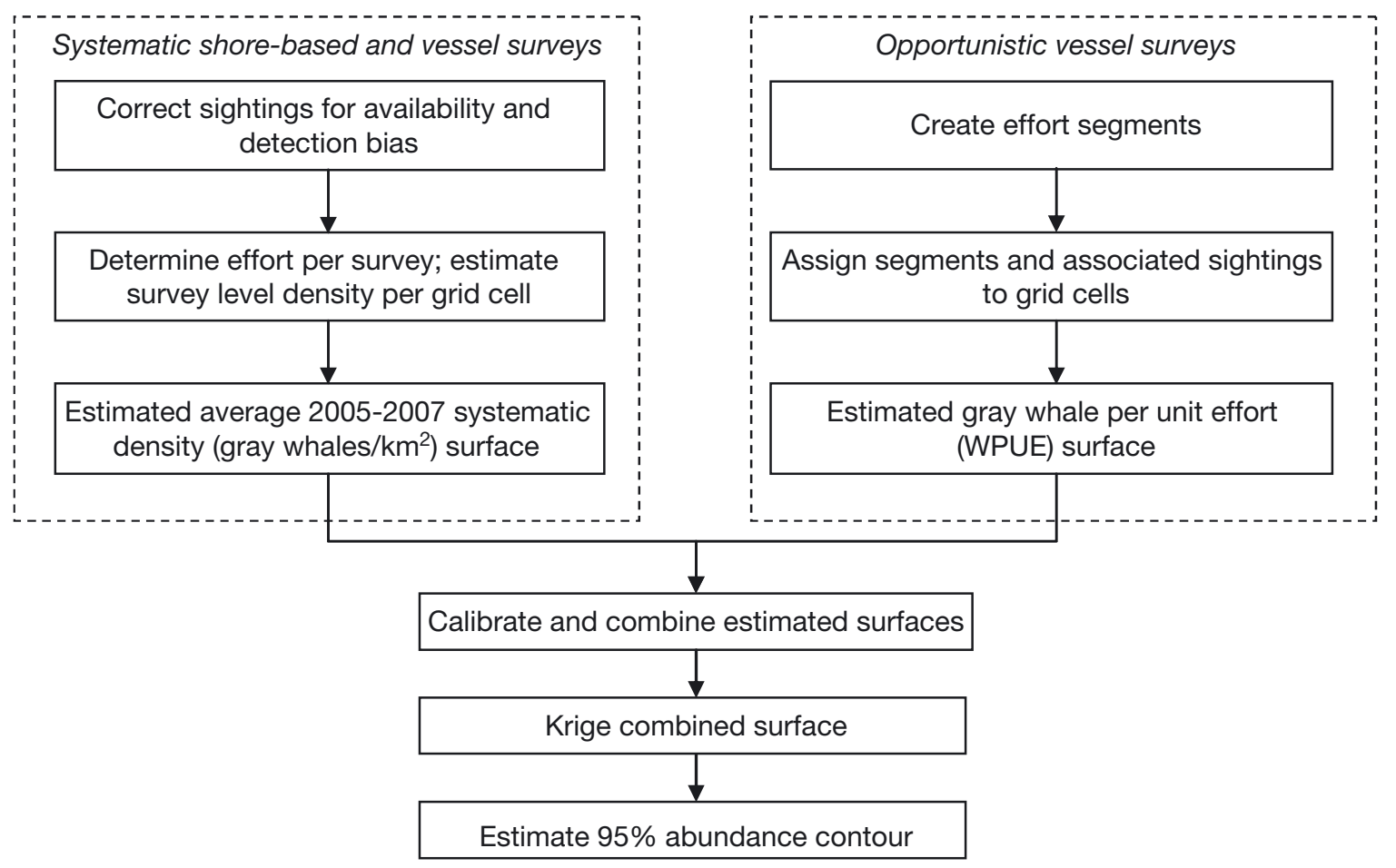

Fig. 2. Schematic showing the analysis steps for estimation of the Piltun feeding area boundary and determination of the acoustic monitoring line. Separate gray whale surfaces were estimated using systematic shore-based and vessel survey effort (top left) and opportunistic vessel survey effort (top right). The surfaces were calibrated and combined, and the resultant surface kriged to produce a smoothed surface from which the $95 \%$ abundance contour for the Piltun feeding area was estimated 
effects of distance and other factors (whale group size, Beaufort Scale, glare, visibility, number of observers, and year) on detection probability of available gray whales for vessel surveys $(\hat{p})$. Due to low sample sizes, Beaufort Scale was categorized only into 'Low' $(0,1)$ and 'Moderate' $(2,3)$, and glare was categorized into 'Light' and 'Severe'. Gray whale sightings made during the Arkutun-Dagi and Offshore vessel surveys throughout June to October from 2006 to 2007 were used to estimate the vessel detection function to increase the sample size and precision of estimates. Surveys in 2005 were excluded because MMOs did not record sighting distance and bearing at time of first detection (see 'Survey effort'). Sightings made during Piltun surveys were also excluded because there is a gray whale density gradient with respect to shore in the Piltun feeding area. The Piltun transects were positioned parallel to shore and thus were parallel to the gray whale density gradient, which violates one of the main assumptions of distance sampling, i.e. that objects are distributed uniformly with respect to distance in any direction from the sampling point (Buckland et al. 2001). Similarly, the gray whale density gradient prevented conventional distance sampling from being used to estimate the shore-based detection function. Instead, we used a double platform (vessel- and shore-based) experiment to estimate the shore-based detection function, which was flat (i.e. detection did not decrease with increasing distance from the observer) up to the $8 \mathrm{~km}$ distance tested, i.e. $\hat{p}_{i, j}=1$ (E. Rexstad \& D. Borchers unpubl.). A gray whale density $\left(\hat{D}_{i, j}\right)$ was estimated in the $j$ th grid cell that was sampled during a particular survey $i$ as follows:

$$
\hat{D}_{i, j}=\frac{1}{\hat{a}_{i, j} A_{i, j}} \sum_{k=1}^{S_{i, j}} \frac{n_{i, j, k}}{\hat{p}_{i, j}}
$$

where $\hat{a}_{i, j}$ is the estimated availability correction for the platform that sampled grid cell $j$ during survey $i_{i} A_{i, j}$ is the area covered by survey $i$ in the $j$ th cell $S_{i, j}$ is the number of sightings by survey $i$ in cell $j_{i} n_{i, j, k}$ is the number of gray whales observed in the $k$ th sighting by survey $i$ in cell $j_{i}$ and $\hat{p}_{i, j}$ was set to 1 as described above for shore-based surveys or estimated for the sighting's distance from the transect using the vessel detection function.

A density of zero was assigned to a sampled grid cell if no gray whales were sighted within it. No density was estimated for unsurveyed grid cells. The estimated survey-level densities across all platforms with effort during June-July 2005-2007 were used to calculate a weighted average within each grid cell, with weights proportional to the amount of area covered in the cell by a survey $\left(A_{i, j}\right)$, to produce the sys- tematic survey density surface. Further details of the density estimation methods may be found in Vladimirov et al. (2011).

\section{Opportunistic WPUE surface estimation}

We used 3 main steps to create a WPUE surface for opportunistic June-July 2005-2007 vessel data: (1) effort segments were constructed from adjacent vessel positions with similar speeds and environmental conditions, (2) distance sampling (Buckland et al. 2001,2004 ) was used to model a detection function for gray whale sightings associated with the effort segments, and (3) WPUE was estimated for each sampled cell of the $1 \mathrm{~km}^{2}$ spatial grid using the effort segments, the right truncation distance of the detection function to represent the approximate width of effort for each segment, and the gray whale sightings. These steps are described in detail below. We included data from August 2005-2007 in the first 2 steps to increase sighting sample size and precision in the estimate of the detection function. However, these data were not used when estimating the WPUE surface.

Segment creation. Vessel effort was mainly provided by GPS tracks. Tracks were not available for 1 of 2 vessels that operated in 2007 . We inferred this vessel's locations from the associated MMO records that noted the vessel location upon record entry. MMOs did not record watch start and end times; they did, however, enter a record at least every $30 \mathrm{~min}$ when on watch. We assumed track locations were off effort if they occurred (1) before the first $\mathrm{MMO}$ record of the day, (2) >30 min after the final MMO record of the day, or (3) were within the first and final MMO records of the day but not within $1 \mathrm{~h}$ of a record, i.e. we assumed MMOs had gone off watch due to poor environmental conditions. All 'off effort' track locations were excluded. Vessel locations associated with reported Beaufort Scale $>4$ (opportunistic effort occurred at Beaufort Scale $\leq 6$ ) were also removed because sighting detection typically deteriorates at higher sea states (Barlow et al. 2001).

Successive retained vessel positions were aggregated into initial segments with similar sighting conditions and speed to ensure similar whale detection conditions within a segment. Only segments with speeds $>5 \mathrm{~km} \mathrm{~h}^{-1}$ were retained because this speed likely exceeded that of feeding gray whales (i.e. mean $1.1 \mathrm{~km} \mathrm{~h}^{-1}$, SD 0.55; Gailey et al. 2009). Slow vessel speeds can inflate encounter rates and associated density estimates because an animal can travel alongside the vessel, or new animals can move into 
the search area (Buckland et al. 2001). Buckland et al. (2001) recommended that average observer speeds be at least 2- to 3-fold greater than that of the animals. Adjacent initial segments were merged with the constraint that the combined segment's total time was $<1.2 \mathrm{~h}$ and total length did not exceed $9 \mathrm{~km}$. Adjacent initial segments were only combined if their difference in speed was $<5 \mathrm{~km} \mathrm{~h}^{-1}$ or if the mean speed was $15 \mathrm{~km} \mathrm{~h}^{-1}$ with the difference in the segments' speed no greater than $10 \mathrm{~km} \mathrm{~h}^{-1}$.

Detection function modelling. Distance v6.0 (Thomas et al. 2010) was used to model a gray whale detection function using perpendicular distances of sightings from their associated segments. North-south segments and associated sightings within $5 \mathrm{~km}$ of shore were excluded due to the whale density gradient with respect to shore and resultant violation of a distance sampling assumption (as described above for the systematic survey detection function modelling). The effects of covariates (visibility, Beaufort Scale, group size, vessel and observer) on detection were tested (Marques \& Buckland 2004). A stepwise forwward selection procedure was used (starting with a model containing perpendicular distance only) to decide which covariates to retain, with a minimum Akaike's information criterion (AIC) inclusion criterion.

WPUE surface creation. June and July 2005-2007 'on effort' segments were used to allocate effort, expressed as times visited, to each $1.0 \mathrm{~km}^{2}$ grid cell in the surface. We adopted a simple approach by using the right truncation distance of the opportunistic sightings detection function as an estimate of the width of effort coverage. Each segment's effort coverage was then created spatially using the ArcGIS v9.2 Buffer tool (ESRI 2007) with the right truncation distance of the detection function as the buffer width. We considered a grid cell to have been effectively covered if that segment's buffer overlapped with that cell's centroid. We applied Hawth's tool 'Enumerate Intersecting Feature' (Beyer 2004) to count the segment buffers that covered each grid cell centroid as an estimate of effort for that cell. The number of gray whales sighted by on-effort segments was summed within each sampled grid cell and divided by that cell's number of segments to derive an estimate of WPUE.

Calibration, merging and smoothing of the systematic and opportunistic surfaces

Estimates in each surface were right-skewed and log-transformed with a constant of 1 added to allow for the log transform of 0 and to reduce the influence of left-skewed outliers. We assessed comparability in surface estimates by evaluating the associated Pearson's correlation coefficient across grid cells sampled at least twice in each surface. These cells were used in a linear regression of the 2 logged datasets assuming an intercept of zero. The logged opportunistic estimates plus constant i.e. $\log (\mathrm{WPUE}+1)$, were multiplied by the regression coefficient $(\beta)$ to calibrate them to the logged systematic estimates plus constant, i.e. $\log \left(\mathrm{WPKM}^{2}+1\right)$.

The 2 surfaces, now both in units of $\log \mathrm{WPKM}^{2}$, were merged by calculating a weighted mean log value for cells with effort in both data sets, with weight proportional to the cell's effort. The log value from the data set with effort was retained in grid cells with no overlap between the surfaces.

Geostatistical kriging methods were used to estimate a smoothed surface across areas with and without survey effort of the merged logged surface. Kriging is a robust and widely used statistical method that uses a variogram-based weighting algorithm to estimate values at missing locations from spatially correlated samples in the neighbourhood (Cressie 1993). We tested 3 kriging approaches (ordinary, simple, and co-kriging). Ordinary kriging assumes strict stationarity (constant spatial mean and variance) but makes no assumptions about the magnitude of the mean (Cressie 1993). Simple kriging assumes both strict stationarity and an a priori known spatial mean over the entire domain including the large offshore region with no survey effort. We assumed a zero mean to stabilize predictions in deeper data-void areas in which no gray whales were observed during aerial surveys in 2001-2003 (Meier et al. 2007). Finally, we assessed the utility of co-kriging that includes a predictive covariate (Matheron 1970). Gray whales have been observed mainly between 5 and $15 \mathrm{~m}$ depth in the Piltun feeding area (Vladimirov et al. 2008). We built a cokriging model using $1 \mathrm{~m}$ bathymetry that was available over the spatial extent of the analysis.

We selected the best variogram structure for each kriging method from a set of candidate variogram functions (exponential, spherical, Gaussian, and Matern) using least squares selection criteria. The variogram function parameters were selected using an ordinary (unweighted) least square optimization function in $\mathrm{R}$ using starting values attained by fitting an empirical variogram to the merged logged surface (fit.variogram, gstat package; R Development Core Team 2012). Potential anisotropy of the spatial autocorrelation was investigated. The spatial distribution of the kriging standard deviation was plotted and visually assessed. 
Feeding area boundary estimation

We determined the upper $95 \%$ of the cumulative frequency in the kriged surface and used the contour function in $\mathrm{R}$ (base package; R Development Core Team 2012) to create the contour line in the surface corresponding to this value.

\section{RESULTS}

\section{Systematic WPKM ${ }^{2}$ surface estimation}

The majority of 2005-2007 systematic survey effort was after the 3rd week of June, with most effort pro-

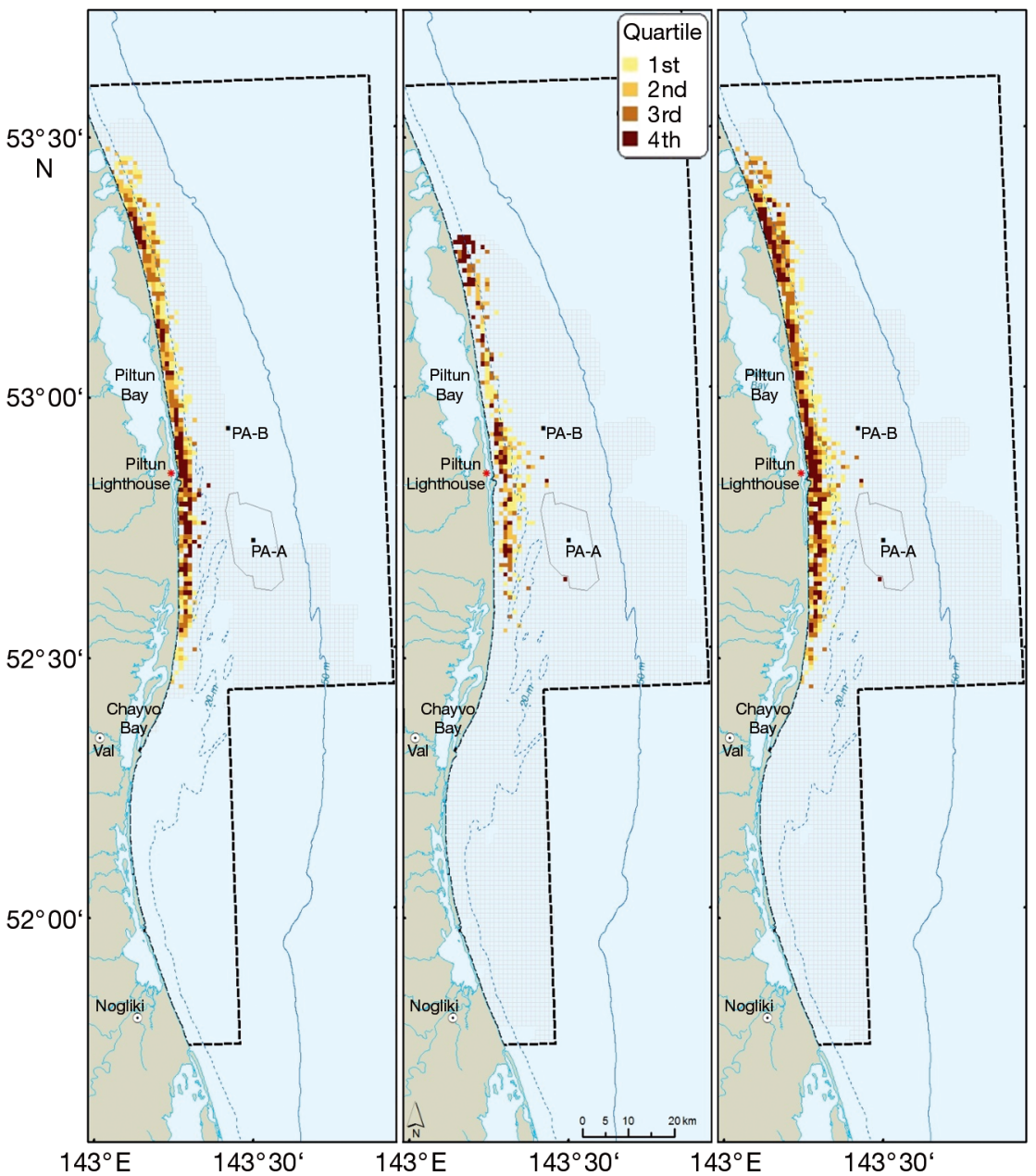

Fig. 3. Effort-corrected relative abundance surfaces for systematic surveys (whales per $\mathrm{km}^{2}$, WPKM ${ }^{2}$; left panel), opportunistic surveys (whales per unit effort, centre panel) and the merged logged surface (right panel), June and July 2005-2007. The spatial extent used for analysis is indicated by the black polygon. Positive (i.e. $>0$ ) values in each surface have been classified into quartiles; light beige-coloured cells had survey effort but no whales were sighted; these cells have an estimated value of zero vided by shore-based scans (Table 2). Only 6 systematic vessel surveys were conducted within the spatial extent of this analysis during June and July 20052007; 4 of these surveys were in 2006 (Table 3).

The estimated shore-based availability correction had a mean of $0.60(\mathrm{SD}=0.038)$. The estimated availability correction for the systematic vessel surveys was 1.0, i.e. the slow vessel speed resulted in gray whales being available on the ocean surface for detection at least once during the time a given area of water was being searched.

The final detection function ( $\mathrm{N}=116)$ used a hazard rate model with no adjustments. The right truncation distance was $5.5 \mathrm{~km}$. AICs indicated no improvements when covariates were added to the base model with distance (Table 4). The mean probability of detection within the right truncation distance was $0.745(\mathrm{SE}=0.044)$.

Values in the estimated WPKM ${ }^{2}$ surface ranged from 0.00 to 0.99 whales $\mathrm{km}^{-2}$ (Fig. 3).

\section{Opportunistic WPUE surface estimation}

One to 2 vessels were in the field during June-August 20052007, with most effort from midJuly through August (Table 5). Substantially more gray whales were seen during August than during June and July.

Table 4. Systematic vessel survey detection function candidate models with AICs. The base detection function that contained distance as a covariate was a hazard rate model with no adjustments and a right truncation distance of $5.5 \mathrm{~km}$. Additional covariates were added singly to the base model. NumObs: number of observers

\begin{tabular}{|lc|}
\hline Model & AIC \\
\hline Base model & 1974.71 \\
Group size & 1976.73 \\
Beaufort Scale & 1976.73 \\
Glare & 1976.73 \\
Visibility & 1976.73 \\
NumObs & 1976.73 \\
Year & 1976.72 \\
\hline
\end{tabular}


Table 5. All opportunistic research vessel effort and gray whale sightings during June-August and June-July from 2005 to 2007. Vessel mobilization dates include all effort on the Sakhalin shelf. Effort (no. of days) during this time within the study area is shown for each time period used in the analysis, with the total number of days the vessel was mobilized on the Sakhalin shelf shown (in parentheses) for comparison. The number of gray whale sightings and total count of gray whales are also shown (in parentheses) for each vessel and time period. '-' indicates no sightings were made due to lack of effort during the time period

\begin{tabular}{|c|c|c|c|c|c|c|c|c|}
\hline \multirow[t]{2}{*}{ Year } & \multirow[t]{2}{*}{ Vessel } & \multirow{2}{*}{$\begin{array}{l}\text { Vessel } \\
\text { mobilization } \\
\text { dates to } \\
31 \text { Aug }\end{array}$} & \multicolumn{3}{|c|}{ June-August } & \multicolumn{3}{|c|}{ - June-July } \\
\hline & & & $\begin{array}{c}\text { Effort within } \\
\text { study area } \\
\text { (days mobilized) }\end{array}$ & $\begin{array}{l}\text { Sightings }(\mathrm{n} \\
\text { within } \\
\text { study area }\end{array}$ & $\begin{array}{l}\text { no. of whales) } \\
\text { on Sakhalin } \\
\text { shelf }\end{array}$ & $\begin{array}{c}\text { Effort within } \\
\text { study area } \\
\text { (days mobilized) }\end{array}$ & $\begin{array}{l}\text { Sightings (n } \\
\text { within } \\
\text { study area }\end{array}$ & $\begin{array}{c}\text { no. of whales) } \\
\text { on Sakhalin } \\
\text { shelf }\end{array}$ \\
\hline 2005 & Lavrentyev & 17 Jul-4 Aug & $17.7(19)$ & $165(243)$ & 165 (243) & $14.8(15)$ & 165 (243) & 165 (243) \\
\hline 2005 & Oparin & 6-31 Aug & $23.8(26)$ & $589(795)$ & $591(797)$ & 0 & - & - \\
\hline 2006 & Bogorov & 21 Jun-31 Aug & $54.7(72)$ & $399(605)$ & $405(618)$ & $25.1(41)$ & $216(321)$ & $218(327)$ \\
\hline 2007 & Bogorov & 9 Jul-31 Aug & $38.7(54)$ & $167(252)$ & $171(258)$ & $16.4(23)$ & $94(146)$ & $94(146)$ \\
\hline 2007 & Oparin & $21 \mathrm{Jul}-31 \mathrm{Aug}$ & $27.6(42)$ & $281(526)$ & $341(678)$ & $4.9(11)$ & $55(124)$ & 74 (169) \\
\hline
\end{tabular}

A total of 5051 on-effort segments, with a total length of $16046.6 \mathrm{~km}$, were designated for JuneAugust 2005-2007 on the Sakhalin shelf. The mean

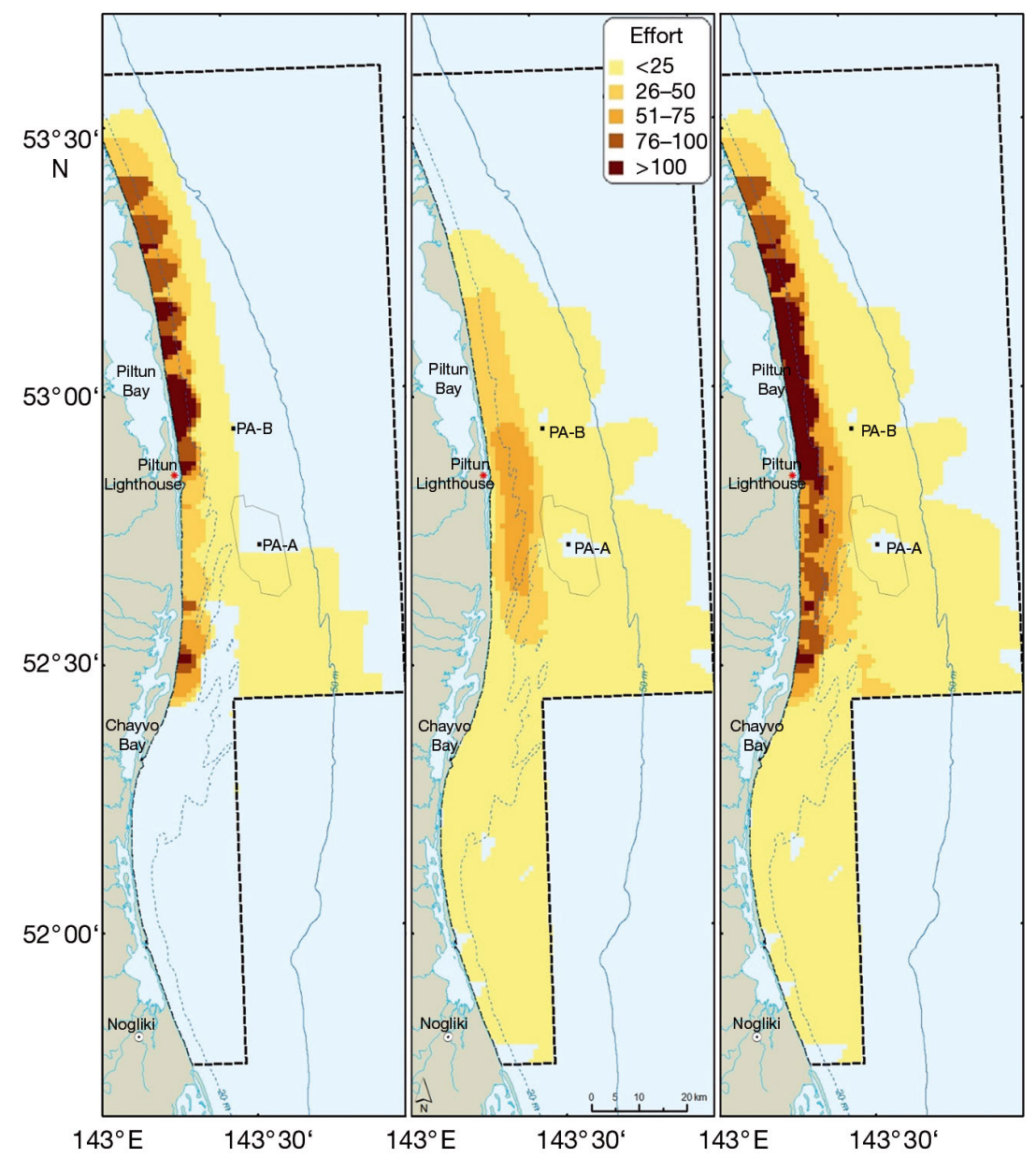

Fig. 4. Systematic (left panel) and opportunistic (centre panel) effort within surface grid cells, June-July 2005-2007. Effort is the number of surveys that sampled a grid cell. The spatial extent used for analysis is indicated by the black polygon. Coverage of the merged logged data set is shown in the right panel segment length was $3.2 \mathrm{~km}$ (range 0.01 to $9.0 \mathrm{~km}$; SD $=1.99$ ) due to gaps in search effort along transects and rejection of segments having speed $<5 \mathrm{~km} \mathrm{~h}^{-1}$. Mean segment speed was $15.6 \mathrm{~km}$ $\mathrm{h}^{-1}$ (range 5.0 to $39.6 \mathrm{~km}$; $\mathrm{SD}=$ 5.06). A total of 1170 sightings were associated with on-effort JuneAugust 2005-2007 segments. The final detection function $(\mathrm{N}=273$ ) used a hazard rate model with covariates of visibility and distance. The right truncation distance was $4.2 \mathrm{~km}$. The mean probability of detection within the right truncation distance was 0.603 (SE = 0.053).

June and July 2005-2007 vessel effort within the spatial extent of this analysis consisted of 1917 segments, with a total length of 5826.5 $\mathrm{km}$. The mean segment length was $3.0 \mathrm{~km}$ (range 0.01 to $9.0 ; \mathrm{SD}=$ 1.95). Mean segment speed was $15.3 \mathrm{~km} \mathrm{~h}^{-1}$ (range 5.1 to $39.4, \mathrm{SD}=$ 5.3). A total of 479 sightings were associated with the 1917 effort segments. The estimated surface (Fig. 3) ranged in value from 0.00 to 2.00 .

\section{Calibration, merging and smoothing of the systematic and opportunistic surfaces}

The spatial extents of the 2 surfaces overlapped, with the exception of north of shore-based Sta- 


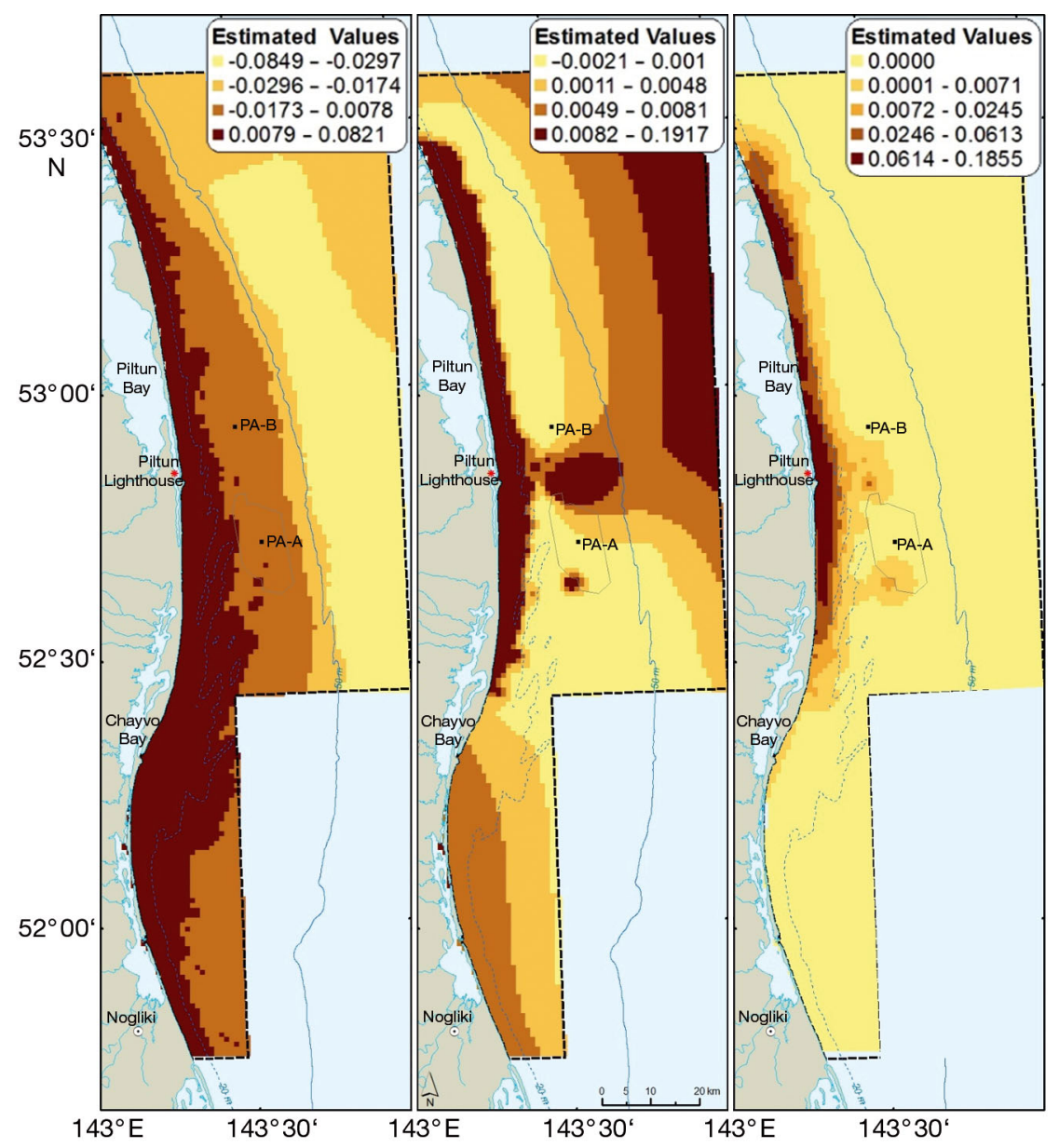

Fig. 5. Estimated surfaces (WPKM ${ }^{2}$ ) using 3 kriging methods. The spatial extent used for analysis is indicated by the black polygon. The left panel shows results from co-kriging using depth as the covariate. Ordinary kriging is shown in the middle panel. The simple kriging surface (right panel) was selected for estimation of the Piltun feeding area $95 \%$ boundary

tion 3, where there was no opportunistic effort, and the coastal area south of shore-based Station 13 that lacked systematic effort. The opportunistic and systematic surfaces had 4533 and 2205 grid cells with effort, respectively, within the analysis spatial extent (Fig. 4). As expected, effort for a given cell differed between the 2 surfaces. Opportunistic surveys occurred mainly in the central part of the Piltun feeding area and within approximately 4 to $8 \mathrm{~km}$ offshore. The majority of shore-based systematic survey effort was concentrated within $5 \mathrm{~km}$ of shore, with most effort in the northern part of the feeding area where most observation stations were located.

The 2 surfaces were significantly correlated in cells with at least 2 units of effort in each surface ( $\mathrm{N}=1585, \mathrm{R}=0.35, \mathrm{p}<0.05$ when zero values were included; $\mathrm{R}=0.26, \mathrm{p}<0.05$ for only non-zero data).
The linear regression had $\mathrm{R}^{2}=0.47(\mathrm{p}$ $<0.05)$ and $\beta=0.92(\mathrm{p}<0.05)$. The combined surface had values ranging from 0.00 to 0.46 , with 4883 grid cells of effort (Figs. $3 \& 4$ ).

Simple kriging performed best of the 3 models to estimate missing values and smooth the combined surface (Fig. 5). The model created a stable extrapolation in data-void areas and estimated abundances that conformed well to raw data. Ordinary kriging produced reasonable estimates in areas with data but resulted in unreasonable extrapolations in data-void areas that were either too high in deep waters of the northeast area or negative in moderate water depths between 20 and $50 \mathrm{~m}$. Co-kriging captured general trends in abundance but predicted poorly in both data-rich and data-poor areas. The cross-variogram indicated a weak negative correlation between abundance and depth, and the depth covariate produced a flat decrease of whale abundance with depth instead of capturing the narrow range of nearshore depths associated with the original abundance data.

An exponential covariance function was selected for fitting the variogram in all kriging models. The variogram values for the simple kriging model included the sill (0.0014), nugget (0.00086), and range $(12 \mathrm{~km})$. The low sill and nugget values were consistent with the low observed kriged values (Fig. 6). The kriging standard deviation across the prediction surface was relatively constant in areas with effort but increased in data-void regions located farther than the variogram range $(12 \mathrm{~km})$ from survey effort. We were unable to get a reasonable estimate of the anisotropy ellipse because the majority of whale observations were within $5 \mathrm{~km}$ of shore.

\section{Feeding area boundary estimation}

The estimated $95 \%$ contour extended $\sim 110 \mathrm{~km}$ along the Sakhalin Island coast and enclosed a continuous $607 \mathrm{~km}^{2}$ nearshore area capturing the region of highest gray whale abundance in the Piltun feed- 


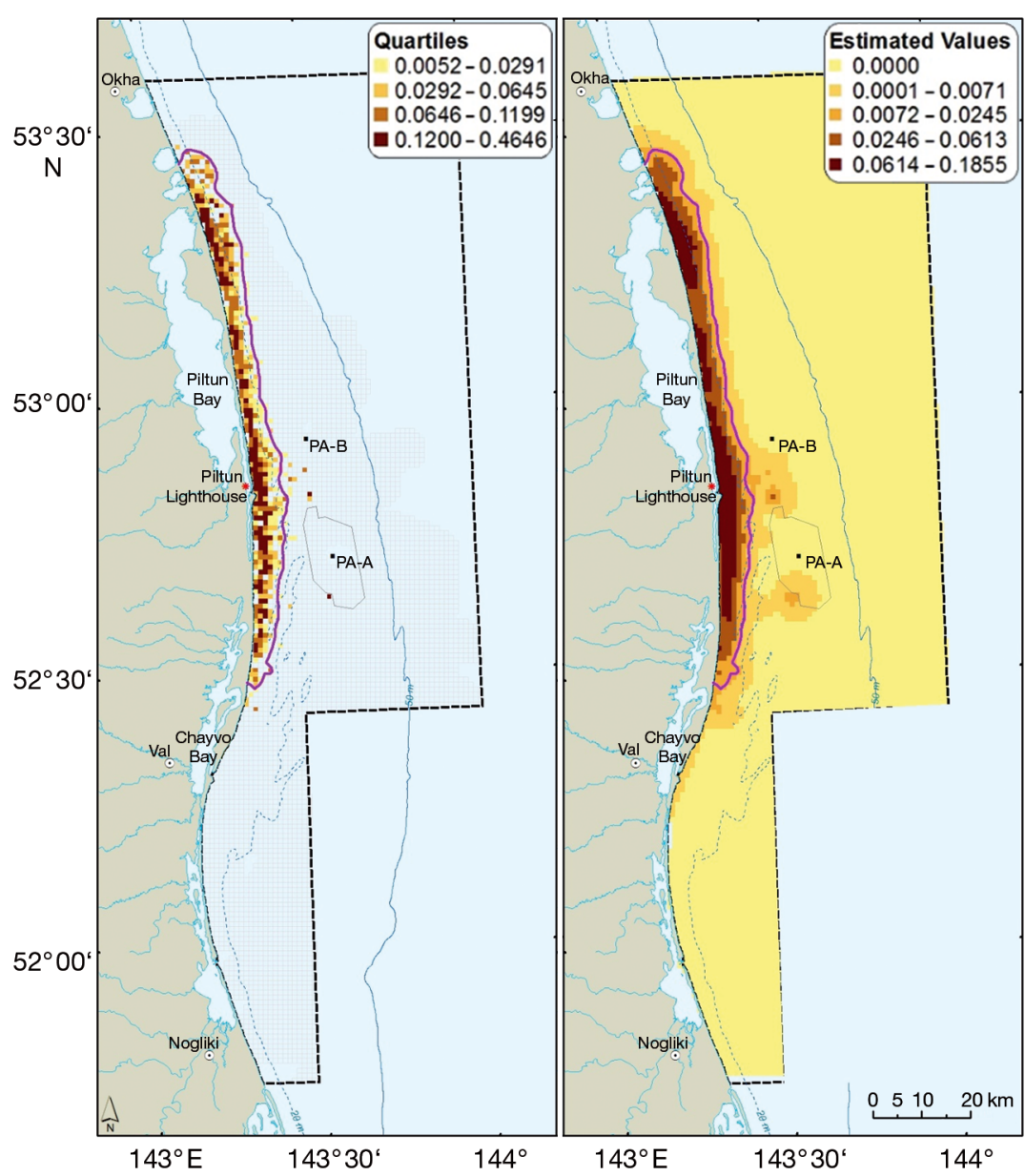

Fig. 6. The 95\% contour line overlaid on the merged logged surface (left panel) and the selected simple kriging surface (right panel); surfaces are in $\mathrm{WPKM}^{2}$. The spatial extent used for analysis is indicated by the black polygon. Positive (i.e. $>0$ ) values in the merged logged surface have been classified into quartiles; light beige-coloured cells had survey effort but no whales were sighted; these cells have an estimated value of zero

ing ground (Fig. 6). The north-south portion of the boundary was an average of $5.4 \mathrm{~km}$ from shore (range 2.3 to $7.1 \mathrm{~km}$ ) with a mean water depth of 24 $\mathrm{m}$ (range: 11 to $35 \mathrm{~m}$ ). As expected, excluded cells were mainly located in deeper waters, or areas to the north or south of concentrations of gray whales observed to date in the feeding ground.

\section{DISCUSSION}

Identifying and delineating critical habitat for species of conservation concern is important when developing management plans and assessing and mitigating potential impacts of anthropogenic activities (Hauser et al. 2007, Williams et al. 2013). Critical habitat for baleen whales includes breeding areas, calving grounds, migration routes, and feeding areas (Gregr \& Trites 2001, Wheeler et al. 2012). We used systematic and opportunistic survey effort to delineate the boundary of the Piltun nearshore feeding area. This boundary supported mitigation measures that aimed to prevent behavioural disturbance of feeding gray whales during a seismic survey conducted adjacent to their feeding ground. The 2 data sets provided complementary spatial coverage throughout the feeding area and its surroundings and improved estimation of the boundary. Systematic data provided little survey effort in deeper waters in the southern part of the feeding ground. Using only these data may have biased the estimated boundary shoreward, which could capture $<95 \%$ of the feeding whales, thus exposing more feeding gray whales to sound levels sufficient to cause behavioural disturbance. Conversely, using only opportunistic surveys with most effort in deeper waters would place the feeding boundary too far offshore, possibly resulting in delays of the seismic survey to avoid disturbing gray whales in deeper waters that may have been transiting instead of feeding. Such delays could have conflicted with the primary mitigation of completing the survey as quickly as possible before many gray whales arrived on their feeding ground (Bröker et al. 2015).

Critical habitat demarcation can be difficult, particularly for mobile and cryptic species such as marine mammals that can also have large geographic ranges (Wheeler et al. 2012). It is crucial to incorporate spatial patterns of relative occurrence or density when identifying critical habitat (Wheeler et al. 2012, Williams et al. 2013). These patterns may be derived directly from survey data, predicted using spatialtemporal models, or based on expert opinion (Williams et al. 2013). Our study directly estimated a smoothed gray whale relative abundance surface from which we derived a $95 \%$ abundance contour as a proxy for the Piltun feeding area boundary. Other marine mammal studies have also used abundance contours estimated from a spatial surface to delineate core habitat and home ranges (e.g. Hobbs et al. 2005, Urian et al. 2009, Williams et al. 2013). Such studies 
frequently use kernel density estimation (KDE) (Worton 1989) to create a smoothed surface from which the contour is derived. However, KDE results are considered sensitive to the smoothing parameter used (Worton 1989, Kie et al. 2010), and the smoothing is applied consistently in all directions (isotropy) (but see Amstrup et al. 2004). This approach assumes that an animal's or species' use of space extends uniformly in all directions (Amstrup et al. 2004), which is not supported for coastal marine mammal distributions. Rayment et al. (2009) addressed this issue by using univariate KDE on coastal Hector's dolphin Cephalorhynchus hectori sightings, which were projected onto a line parallel to shore, whereas Amstrup et al. (2004) modelled a 2D kernel that estimated smoothing distances separately for the $\mathrm{X}$ and $\mathrm{Y}$ dimensions.

We used kriging (Cressie 1993) to smooth our coastal gray whale density surface because the spatial smoothing was estimated from the observations through a variogram that can incorporate directionality (anisotropy). Kriging models allow additional information such as covariates and assumed spatial means to be used for predictions. We were unsuccessful in modelling an anisotropic variogram to capture the long, narrow shape of the gray whale distribution because the empirical variogram in the east-west direction had no asymptote to indicate a $\mathrm{km}$ range at which data points became independent, and we were unable to estimate a reasonable range parameter in this direction. In addition, our data contained many observed zeros in offshore areas that confounded variogram estimation in the eastwest direction. We therefore used an isotropic variogram model that smoothed equally in all directions. The estimated unidirectional smoothing amount was a compromise that likely was too great in the east-west direction and undersmoothed the northsouth direction. The estimated contour was thus likely located farther offshore and was more protective of whale habitat compared to a contour from an estimated surface using anisotropic smoothing. Improvements to the kriging could be made by blocking the study area and fitting variograms separately to cohesive regions of similar stationarity and by including, if available, additional covariates associated with gray whale habitat use (e.g. locations with high prey biomass).

Separate detection functions and values to correct for availability (probability of detecting a gray whale at the surface) were estimated for each platform (vessel and shore-based) used in the systematic survey relative density surface. Borchers et al. (2013) sug- gested that the McLaren (1961) availability correction used in our estimates can be biased, with differing amounts of bias for the 2 platforms. Given the low number of systematic vessel surveys, it is unlikely that this source introduced substantial bias into the density surface. The availability correction for shorebased density estimates was a constant; thus, its bias would equally affect all density estimates in the surface. The shore-based detection function had limitations in that effects of environmental covariates were not tested due to low sample sizes. It is possible that detection at farther distances decreased as environmental conditions (e.g. visibility or Beaufort Scale) deteriorated, resulting in underestimation of densities. Inclusion of the greater opportunistic surface effort in deeper waters of the feeding area may have helped reduce this potential bias.

The rules for delineating effort segments for the opportunistic vessel survey tracks provided a nominal but reasonable method of identifying on-effort segments in the absence of formal observer declarations of going 'on' and 'off' effort. The use of daylight hours and environmental conditions conducive to observing gray whales likely minimized the number of 'off' effort segments with zero sightings that were mistakenly taken as 'on' effort and would negatively bias WPUE estimates. The opportunistic survey effort coverage was based on the modelled detection function right truncation distance. Gray whale detection during opportunistic surveys may have been affected by use of different vessels and different observers. However, these vessels had comparable observer platform height, and potential covariates affecting detection such as observer and environmental conditions were tested. As absolute abundance was not required, no attempt was made to estimate an availability correction value. This probability was assumed constant across the study area. This may not be the case if, for example, whales surface at different rates at different depths.

The estimated boundary corresponded well to historically observed whale use in the feeding ground and captured regions of highest abundance. The boundary was determined specifically for the June to July time period when gray whales are migrating into the feeding area and abundance is relatively low compared to later in the season. Use of the boundary should therefore be limited to the same June to July time frame for which the boundary was developed. However, our methods can be applied to re-estimate the boundary for a different time period or used as a framework to delineate important habitat for other species. 
Acknowledgements. This paper is the result of work carried out at a workshop held 23-26 October 2009 at IUCN headquarters in Gland, Switzerland. We gratefully acknowledge the work of Dr. Charles Paxton (CREEM, University of St. Andrews) to create the opportunistic vessel effort segments and the associated detection function model that were used to estimate the opportunistic vessel survey WPUE surface. We thank R. Reeves, G. Donovan and an anonymous reviewer whose comments improved this manuscript. We thank Doug Bell and Rob Ryan (Sakhalin Energy) for support during the analysis. Dorine Terwogt (Sakhalin Energy) provided a helpful review of the kriging portion of this study. We appreciate mapping assistance by Lucia Ferreira and Robin Tamasi (LGL Limited). Julio Novoa (LGL Limited) prepared map figures. The ideas of and constructive discussions with members of the IUCN Western Gray Whale Advisory Panel's Seismic Survey Task Force are greatly appreciated. We particularly acknowledge the contribution of A. Vedenev who suggested the work presented in this manuscript. This study was funded by Sakhalin Energy Investment Company.

\section{LITERATURE CITED}

Amstrup SC, McDonald TL, Durner GM (2004) Using satellite radiotelemetry data to delineate and manage wildlife populations. Wildl Soc Bull 32:661-679

Barlow J, Gerrodette T, Forcada J (2001) Factors affecting perpendicular sighting distances on shipboard linetransect surveys for cetaceans. J Cetacean Res Manag 3: 201-212

Beyer HL (2004) Hawth's analysis tools for ArcGIS. Available at www.spatialecology.com/htools

Borchers DL, Zucchini W, Heide-Jørgensen MP, Cañadas A, Langrock R (2013) Using hidden Markov models to deal with availability bias on line transect surveys. Biometrics 69:703-713

Bröker KC, Gailey G, Muir JE, Racca R (2015) Monitoring and impact mitigation during a 4D seismic survey near a population of gray whales off Sakhalin Island, Russia. Endang Species Res 28:187-208

Buckland ST, Anderson DR, Burnham KP, Laake JL, Borchers DL, Thomas L (2001) Introduction to distance sampling: estimating abundance of biological populations. Oxford University Press, Oxford

Buckland ST, Anderson DR, Burnham KP, Laake JL, Borchers DL, Thomas L (2004) Advanced distance sampling: estimating abundance of biological populations. Oxford University Press, Oxford

Cressie N (1993) Statistics for spatial data, revised edn. Wiley, New York, NY

ESRI (2007) ArcGIS software products. Environmental Systems Research Institute, Redlands, CA

Fadeev VI (2013) Benthos studies in the feeding grounds of gray whales, 2012. In: Western (Okhotsk-Korean) gray whale monitoring program off the northeast coast of Sakhalin Island, 2012. Vol 2: Results and discussion. Prepared for Exxon-Neftegas Ltd. and Sakhalin Energy Investment Company, Yuzhno-Sakhalinsk, p 246-311. Available at: https://cmsdata.iucn.org/downloads/wgwap_ 13_8_wgw_research_and_monitoring_program_in_2012_ sakhalin_island_russia_volu.pdf (accessed 10 Feb 2014)

Fadeev VI, Gailey G, Tyurneva OY, Yakovlev Y, Vladimirov VA, Muir JE (2012) Sakhalin gray whale research and monitoring background. In: Western gray whale moni- toring program in 2012, Sakhalin Island, Russia. Vol 1: Background and methods. Prepared for Exxon-Neftegas Ltd. and Sakhalin Energy Investment Company, YuzhnoSakhalinsk, p 11-32. Available at http://cmsdata.iucn. org/downloads/2011_mnr_report_vol_i_methods_eng_ final.pdf (accessed 10 Feb 2014)

> Gailey G, Würsig B, McDonald T (2007a) Abundance, behaviour, and movement patterns of western gray whales in relation to a 3-D seismic survey, Northeast Sakhalin Island, Russia. Environ Monit Assess 134:75-91

Gailey G, Sychenko O, Würsig B (2007b) Western gray whale behavior, movement, and occurrence patterns off Sakhalin Island, 2006. Prepared for LGL ecological research associates Ltd., for Exxon-Neftegas Ltd. and Sakhalin Energy Investment Company, Yuzhno-Sakhalinsk. Available at: www.sakhalinenergy.ru/media/d8ff2be2-8093-481c-b581bde59419d759.pdf (accessed 5 Sep 2013)

Gailey G, Sychenko O, Würsig B (2008) Patterns of western gray whale behavior, movement and occurrence off Sakhalin Island, 2007. Prepared for LGL ecological research associates Ltd., for Exxon-Neftegas Ltd. and Sakhalin Energy Investment Company, Yuzhno-Sakhalinsk. Available at: www.sakhalinenergy.ru/media/2a760f68ea52-4d66-a1cd-5951c7c4f88f.pdf (accessed 5 Sep 2013)

Gailey G, Sychenko O, Würsig B (2009) Patterns of western gray whale behavior, movement and occurrence off Sakhalin Island, 2008. Prepared for LGL ecological research associates Ltd., for Exxon-Neftegas Ltd. and Sakhalin Energy Investment Company, Yuzhno-Sakhalinsk. Available at: http://cmsdata.iucn.org/downloads/ wgwap_6_13e_behaviour_monitoring_report_2008.pdf (accessed 5 Sep 2013)

> Gregr EJ, Trites AW (2001) Predictions of critical habitat for five whale species in the waters of coastal British Columbia. Can J Fish Aquat Sci 58:1265-1285

> Hauser DDW, Logsdon MG, Holmes EE, Van Blaricom GR, Osborne RW (2007) Summer distribution patterns of southern resident killer whales Orcinus orca: core areas and spatial segregation of social groups. Mar Ecol Prog Ser 351:301-310

Hobbs RC, Laidre KL, Vos DJ, Mahoney BA, Eagleton M (2005) Movements and area use of belugas, Delphinapterus leucas, in a subarctic Alaskan estuary. Arctic 58:331-340

IUCN (2007) Report of the seismic survey task force at its 1st meeting 25-28 June 2007. IUCN, Gland. Available at: https://cmsdata.iucn.org/downloads/seismic_tf__report_ final_20_09_07_with_caution_20_05_08_1.pdf (accessed 10 Feb 2014)

IUCN (2008) Report of the seismic survey task force at its $2^{\text {nd }}$ meeting 13-16 March 2008. IUCN, Gland. Available at: https://cmsdata.iucn.org/downloads/seismic_task_force _report_final__30_06_08.pdf (accessed 10 Feb 2014)

Kie JG, Matthiopoulos J, Fieberg J, Powell RA and others (2010) The home-range concept: are traditional estimators still relevant with modern telemetry technology? Philos Trans R Soc Lond B 365:2221-2231

- Laver P, Kelly J (2008) A critical review of home range studies. J Wildl Manag 72:290-298

> Ljungblad DK, Würsig B, Swartz SL, Keene JM (1988) Observations on the behavioral responses of bowhead whales (Balaena mysticetus) to active geophysical vessels in the Alaskan Beaufort Sea. Arctic 41:183-194

Malme CI, Würsig B, Bird JE, Tyack P (1986) Behavioral responses of gray whales to industrial noise: feeding 
observations and predictive modeling. Outer Continental Shelf Environmental Assessment Program, US Dept. of Commerce, NOAA, OCSEAP Final Rep 56:393-600. Available at: www.arlis.org/docs/vol1/OCSEAP2/Final/ 12824468/F\%20v56.pdf (accessed 25 Nov 2015)

Marques FFC, Buckland ST (2004) Covariate models for the detection function. In: Buckland ST, Anderson DR, Burnham KP, Laake JL, Borchers DL, Thomas L (eds) Advanced distance sampling. Oxford University Press, Oxford, p 31-47

Marsh H, Sinclair DF (1989) Correcting for visibility bias in strip transect aerial surveys of aquatic fauna. J Wildl Manag 53:1017-1024

Matheron G (1970) La théorie des variables régionalisées et ses applications. MSc dissertation, Paris School of Mines, Fontainebleau. Available at http://cg.ensmp.fr/ bibliotheque/public/MATHERON_Ouvrage_00161.pdf (accessed 15 Apr 2014)

McCauley RD, Fewtrell J, Duncan AJ, Jenner C and others (2000) Marine seismic surveys - a study of environmental implications. APPEA J 40:692-708

McLaren IA (1961) Methods for determining the numbers and availability of ringed seals in the eastern Canadian Arctic. Arctic 14:162-175

Meier SK, Yazvenko SB, Blokhin SA, Wainwright P, Maminov MK, Yakovlev YM, Newcomer M (2007) Distribution and abundance of gray whales off northeastern Sakhalin Island, Russia, 2001-2003. Environ Monit Assess 134:107-136

Nowacek DP, Thorne LH, Johnston DW, Tyack PL (2007) Responses of cetaceans to anthropogenic noise. Mammal Rev 37:81-115

R Development Core Team (2012) R: a language and environment for statistical computing. R Foundation for Statistical Computing, Vienna

Rayment W, Dawson W, Slooten E, Bräger S, Du Fresne S, Webster T (2009) Kernel density estimate of alongshore home range of Hector's dophins at Banks Peninsula, New Zealand. Mar Mamm Sci 25:537-556

Reeves RR, Ljungblad DK, Clarke JT (1984) Bowhead whales and acoustic seismic surveys in the Beaufort Sea. Polar Rec 22:271-280

Richardson WJ, Würsig B, Greene CR Jr (1986) Reactions of bowhead whales, Balaena mysticetus, to seismic exploration in the Canadian Beaufort Sea. J Acoust Soc Am 79: 1117-1128

Richardson WJ, Greene CR Jr, Malme CI, Thomson DH (1995) Marine mammals and noise. Academic Press, San Diego, CA

Richardson WJ, Miller GW, Green CR Jr (1999) Displacement of migrating bowhead whales by sounds from seismic surveys in shallow waters of the Beaufort Sea. J Acoust Soc Am 106:2281

Sychenko OA (2011) Western gray whale (Eschrichtius robustus) mother and calf ecology off Sakhalin Island. MSc thesis, Texas A\&M University. Available at http://oaktrust. library.tamu.edu/bitstream/handle/1969.1/ETD-TAMU2011-05-9112/SYCHENKO-THESIS.pdf (accessed 1 Jul 2014)

Thomas L, Buckland ST, Rexstad EA, Laake JL and others (2010) Distance software: design and analysis of distance sampling surveys for estimating population size. J Appl Ecol 47:5-14

Urian KW, Hofmann S, Wells RS (2009) Fine-scale population structure of bottlenose dolphins (Tursiops truncatus) in Tampa Bay, Florida. Mar Mamm Sci 25:619-638
Vladimirov VA, Starodymov SP, Ashchepkov AT, Afanasyev-Grigoryev AG, Muir JE, Vladimirov AV (2007) Distribution and abundance of gray whales of the Okhotsk-Korean population in the waters of northeastern Sakhalin in June-October 2006 (based on data from onshore and vessel-based surveys). Final report by the All-Russian Research Institute of Fisheries and Oceanography (VNIRO), Moscow. Prepared for Exxon Neftegas Ltd. and Sakhalin Energy Investment Company Ltd., Yuzhno-Sakhalinsk. Available at: www.sakhalinenergy .ru/media/user/libraryeng/environmental/westerngray whales/Distribution_en_06.pdf (accessed 1 Feb 2014)

Vladimirov VA, Starodymov SP, Afanasyev-Grigoryev AG, Muir JE (2008) Distribution and abundance of Korean stock gray whales in the waters of northeastern Sakhalin during June-October 2007 (based on data from onshore and vessel-based surveys). Final report by the All-Russian Research Institute of Fisheries and Oceanography (VNIRO), Moscow. Prepared for Exxon Neftegas Ltd. and Sakhalin Energy Investment Company Ltd., YuzhnoSakhalinsk. Available at: www.sakhalinenergy.ru/media/ user/libraryeng/environmental/westerngraywhales/ Distribution_en_07.pdf (accessed 1 Feb 2014)

Vladimirov VA, Starodymov SP, Afanasyev-Grigoriyv AG, Muir JE (2011) Western gray whale distribution surveys (vessel-based and onshore): introduction and methods. Final report by the All-Russian Research Institute of Fisheries and Oceanography (VNIRO), Moscow. In: Western gray whale research and monitoring program in 2010, Sakhalin Island, Russian Federation. Vol I: Background and methods. Prepared for Exxon Neftegas Ltd. and Sakhalin Energy Investment Company Ltd., YuzhnoSakhalinsk, p 34-62. Available at: http://cmsdata.iucn.org/ downloads/wgwap_10_doc_12_2010_mnr_report_volume _i_methods__eng__29_apr.pdf (accessed 5 Sep 2013)

Vladimirov VA, Starodymov SP, Korniyenko MS, Kalachev AV (2013) Distribution and abundance of gray whales in northeast Sakhalin in August-September 2012 (based on data from shore-based and vessel-based surveys). Final report by the All-Russian Research Institute of Fisheries and Oceanography (VNIRO), Moscow, Russia. In: Western (Okhotsk-Korean) gray whale monitoring program off the northeast coast of Sakhalin Island, 2012. Vol 2: Results and discussion. Prepared for Exxon Neftegas Ltd. and Sakhalin Energy Investment Company Ltd., YuzhnoSakhalinsk, p 4-170. Available at: https://cmsdata. iucn.org/downloads/wgwap_13_8_wgw_research_and_ monitoring_program_in_2012_sakhalin_island_russia_ _volu.pdf (accessed 10 Nov 2013)

Wheeler B, Gilbert M, Rowe S (2012) Definition of critical summer and fall habitat for bowhead whales in the eastern Canadian Arctic. Endang Species Res 17:1-16

Williams R, Grand J, Hooker SK, Buckland ST and others (2013) Prioritizing global marine mammal habitats using density maps in place of range maps. Ecography 36: 001-009

Worton BJ (1987) A review of models of home range for animal movement. Ecol Modell 38:277-298

Worton BJ (1989) Kernel methods for estimating the utilization distribution in home-range studies. Ecology 70 : $164-168$

Yazvenko SB, McDonald TL, Blokhin SA, Johnson SR and others (2007) Distribution of western gray whales during a seismic survey near Sakhalin Island, Russia. Environ Monit Assess 134:45-73 